\title{
Thematic Structure in the Arabic Translations of Edgar Allan Poe's The Black Cat, The Tell-Tale Heart and Virginia Woolf's A Haunted House
}

\author{
Bahaa-Eddin Abulhassan Hassan \\ Department of English, Faculty of Arts, Sohag University, Sohag, Egypt
}

Email address:

bahaassan@yahoo.com

To cite this article:

Bahaa-Eddin Abulhassan Hassan. Thematic Structure in the Arabic Translations of Edgar Allan Poe's The Black Cat, The Tell-Tale Heart and Virginia Woolf's A Haunted House. International Journal of Language and Linguistics. Vol. 3, No. 3, 2015, pp. 132-139.

doi: $10.11648 /$ j.ijll.20150303.14

\begin{abstract}
The purpose of this study is to examine thematic structure in the translations of Edgar Allan Poe's The Black Cat, The Tell-Tale Heart and Virginia Woolf's A Haunted House. Meaning in Gothic literary works is closely associated with word order. The study aims at discussing the problems arising from the differences between English and Arabic in the degree of reliance on thematic structure. The study shows how markedness, topicalization and focus are considered as possible problems of literary translation from English into Arabic. The study utilizes Thematic Structure Theory to analyze the marked sentences in the translations of these literary texts.
\end{abstract}

Keywords: Thematic Structure, Markedness, Topicalization, Focus

\section{Introduction}

Literary texts are expressive, symbolic, subjective and using special devices to convey implicit meaning. They often deviate from the language norms to 'heighten' a communicative effect. Horror fiction as a literary genre draws heavily on preposing constructions to deliver a communicative effect. The readers' understanding of implicit meaning inferred by these constructions is part of their pragmatic information. Some translators do not pay attention to these pragma-stylistic aspects of horror fiction. Blatant disregard for these features would result in effect loss in the target text.

\section{Significance and Scope of the Study}

The study is significant because many literary translations ignore the aspects of markedness, topicalization and focus. The study shows how some preposed marked items used in English literary texts, are made unmarked in Arabic literary translations and vice versa. The reason is that Arabic, unlike English, does not have restricted word order in its system and thus, is more flexible. Markedness functions as a facet of the relationship between form and meaning of a text. The discussion is restricted here to Edgar Allan Poe's The Black
Cat, The Tell-Tale Heart and Virginia Woolf's A Haunted House as literary texts where the analyzed data is extracted. The discussion excludes grammatical issues in translation because they are irrelevant to the analysis of the data which mainly focuses on handling textual-related problems. Transformational analysis is beyond the scope of the study. Linguistic markedness is receiving more elaboration than other stylistic devices which will be touched upon in respect of their relevance to textual equivalence.

\section{Research Problems}

The research problem for this study is to provide an account of thematic structure options in English as compared to Arabic. The study brings the literature on thematic structure through a consideration of the following research questions:

How are markedness, topicalization and focus used in English and Arabic?

1 What is the function of fronted structures in horror fiction?

2 How can markedness be rendered in translated literary texts? 


\section{Objectives of the Study}

The main objectives of the study are:

1 to investigate marked structures in English, topicalization and focus in Arabic,

2 to identify the function of fronted structures in horror fiction, and

3 to identify the suitable ways of translating marked structures in literary texts

\section{Literature Review}

Thematic structure is one of the central issues which have attracted the attention of many scholars. Reflection on this aspect of language was launched by the Prague School which focused on 'functional grammar'. Halliday (1985/1994) wrote An Introduction to Functional Grammar. Bloor and Bloor (1995: 82) argue that "Markedness is a concept which is useful in the language study as a whole". Markedness has been extensively explored and applied in various fields of linguistics such as phonology, morphology, semantics, and syntax since last century; however, in this study syntactic markedness is intended rather than any other types. Menacere (1995) considers word order in English and Arabic. Dickens and others (2002) wrote a chapter about theme and rheme in their book Thinking Arabic Translation, a course in translation method.

Markedness is manipulated in Gothic horror fiction. First, one tends to exhibit discursive affiliation of the Gothic genre; the wider socio-cultural perspectives. Gothic fiction, sometimes referred to as Gothic horror, is a genre or mode of literature that one can trace its history in the eighteenth century during the English romantic period with Mary Shelley's Frankenstein and the works of Edgar Allan Poe. Jones (2010) describes Gothic fiction through its language (key words and lexico-grammatical patterning) to reveal insights about the genre of Gothic fiction. He uses Corpus Stylistics as an empirical approach to explore the uses of language in eleven Gothic novels. His study demonstrates that there was a high frequency of words of "Feelings, Setting, and Supernatural or Uncertain State of Being" (Jones 2010:23). Meaning in the Gothic genre is closely associated with word choice and word order. The reader is not only told what is happening but actually feels what the narrator feels (Jones 2010: 28) According to McEvoy (2007), "novels achieve their effect through empathetic response. As readers, we become subject to the terrors of a world which to a large extent is created by the mind of the protagonist" (2007: 23). The tendency to use embedded structures is one of the main conventions. The complex framing keeps the readers in suspense because they cannot predict what will happen (Jones 2010: 28). Gothic fiction is often associated with dark isolated settings and the supernatural, monstrosity, and Faustian plots (Sedgwick 1986). Some concepts are practically popular: the past, the blurred line between reality and fantasy and the changing roles and psychologies of men and women. Hogle (2002) suggests that Gothic literature "helps us address and disguise some of the most important desires, quandaries, and sources of anxiety, from the most internal and mental to the widely social and cultural throughout the history of western culture from the eighteenth century" (2002: 4). It provides a link between the past and the present. Hatim (2004: 232) argues that "Flower (1986: 223) shows how, ..., 'the Gothic genre indulges its heroes and heroines in morbid feelings and sensational imaginings"”. Hatim notes that the defamiliarizing effect in the Gothic novels is achieved by certain devices of linguistic expressions such as emotive diction and word order. It is considered an expectation-defying use of language (2004: 232). In translating a Gothic genre very close attention must be paid to the way structure and texture are made. Hatim stresses "the need to translate not only 'what' is said, but also 'how' it is said (2004: 229).

\section{Data Collection and Methodology}

The data in the study are excerpts from Edgar Allan Poe's The Black Cat, The Tell-Tale Heart and Virginia Woolf's $A$ Haunted House and their Arabic translations. The criterion for the selection of the excerpts is based on marked structures in the source texts. Some excerpts are examples of partially marked structures and others are examples of marked ones. The marked and partially marked sentences in the source texts will be compared with their Arabic translations. The study starts by providing a theoretical framework defining linguistic markedness, topicalization and focus, and then it moves to the discussion of the different ways of using markedness in the source texts. Because of differences in thematic structure between English and Arabic different criteria will be used. In describing the source text structures three Hallidayan criteria will be used:

1 unmarked

2 partially marked

3 marked

In the description of the target text structure two criteria will be used in accordance with Ford (2009):

1 topicalized

2 focused

Transliteration and case-marked glossary of the Arabic sentences are only used in the theoretical part to show topicalization and focus which are based on case marking. The study shows topic-comment structures and focus structures in the target texts. Marked, topicalized and focus structures are indicated in the study by underlining the constituent for clarity. The data are analyzed to see how translators dealt with the problems posed by the use of linguistically marked items. This study is a qualitative, descriptive-analytical one. It tries to describe, analyze and explain the problem of study using corpus driven data.

\section{Theoretical Framework}

Now, before moving to the analysis of our data, it is appropriate to outline the framework for the analysis of 
markedness in English and topicalization and focus in Arabic. The study uses Thematic Structure Theory as a theoretical framework.

\subsection{Thematic Structure Theory}

It is traditionally acknowledged that the clause has two parts: the topic and the complement of topic. Various linguists differ on various aspects of Thematic Structure Theory. Theme is 'what the clause is about'. The rest of the clause is called rheme. The literature on Thematic Structure Theory is characterized by an absence of uniformity of terminology. 'Topic' and 'ground' are other terms for 'theme', while 'focus' and 'comment' are used as terms for 'rheme'. The topic-focus distinction is always related to the division between 'given' and 'new' information in a sentence. It is logically acknowledged that thematic structure mirrors the information structure of a text.

According to the Hallidayan model, there are three types of theme in English:

Table 1. Subject theme (unmarked theme).

\begin{tabular}{ll}
\hline John & meets Mary \\
\hline Theme & Rheme \\
\hline
\end{tabular}

Table 2. Adjunct theme (partially marked) .

\begin{tabular}{ll}
\hline On a clear day, & you can travel \\
\hline Theme & Rheme \\
\hline
\end{tabular}

Table 3. Fronted objects and complements (marked themes).

\begin{tabular}{ll}
\hline Fish & I like \\
\hline Theme & Rheme \\
A good bargain & it is not! \\
Theme & Rheme \\
\hline
\end{tabular}

Berry (1995), on the other hand, distinguishes between the 'Basic Theme', which will in general be the Subject, and 'Additional Themes', which accounts for all fronted Adjuncts and complements.

\begin{tabular}{lll}
\hline On a clear day, & you & can travel \\
\hline Additional Theme & Basic Theme & Rheme \\
\hline
\end{tabular}

In accordance with Kirkwood (1979), Baker states that "placing an element in initial position will give it a certain prominence but that it will still carry less weight than the actual rheme" (1992: 132). In English literary texts, in particular, the use of clefting or fronting is motivated since they guarantee deviation from norms which characterize this type of discourse. English uses clefting or fronting in the gloss to emphasize the constituent. It is scholarly accepted that grammatical components in English are determined positionally and there are constraints on word order. English is known with rigidity of structure; declarative sentences in English follow a fixed order of constituents. The topicalization of arguments in English is rare, whereas circumstantial adjuncts are often topicalized. Unlike English, Arabic is more tolerant and flexible in the movement of its components (Menacere 1995: 608). In Arabic word order is more flexible because the roles of sentence constituents are clarified by case markings and agreement.

Arabic uses various word orders, and such flexibility is an advantage of Arabic. On the contrary, English has stricter rules of syntax, and cannot always adopt a similar flexibility to prepose and emphasize information. Clefting is one of the methods English uses to emphasize any part of a sentence. Marked word order in Arabic can be seen in moving forward or preposing of the subject or the object, such as OVS and other complex orders.

Because of the varied word order permutations in Modern Standard Arabic (MSA) there has been confusion between topic and focus. Ford (2009) differentiates between topiccomment structures and focus structures in Modern Standard Arabic. The topic/focus dichotomy is used as a syntactic category having semantic/pragmatic value. In order to show the difference between topic and focus, the study postulates that, given that VSO is the default structure (Bakir 1979: 810 ), any other structures are transformationally derived from VSO structure. It is generally agreed by grammarians that the unmarked word order in Arabic is VSO.

$$
\begin{aligned}
& \text { (1) أكل الولد الخبز ?akala ? al-waladu ?al-xubza } \\
& \text { Ate Def-boy- NOM Def-bread-ACC } \\
& \text { The boy ate the bread. }
\end{aligned}
$$

Word order variation in MSA includes topic-comment structures and focus Structures. Case marking is the key distinction between topic-comment structures and focus Structures. On the one hand, the first argument in topiccomment structures is in the nominative case. The following sentences are examples of topic-comment structures.

الولا أكل الخبز (2)

?al-waladu ?akala ?al-xubza

Def-boy- NOM ate Def-bread-ACC

The boy, he ate the bread.

الخبز الولد أكله (3) (3) (2)

?al-xubzu ?al-waladu ?akalahu

Def-bread-NOM Def-boy- NOM ate-it

The bread, the boy ate it.

الخبز أكله الولد (4)

?al-xubzu ?akalahu ?al-waladu

Def-bread-NOM ate-it Def-boy- NOM

The bread, the boy ate it.

الولا الخبز أكل (5)

?al-waladu ?al-xubza?akala

Def-boy- NOM Def-bread-ACC ate

The boy, it was the bread that he ate.

(SOV)

Notice that both the subject and the object can be topicalized via topic-comment structure. If the object is in the nominative case, there is an obligatory resumptive pronoun (hu) which attaches to the verb. Topic-comment structures are based on 
the nominative case initial position. There has been a controversy over the verbal sentence and the nominal sentence. It has been argued that SVO structure as well as the equative (verbless) sentence is a nominal sentence. Both equative sentences and nonequative SVO sentences begin with a noun in the nominative case. There has been an argument against SVO structure which is considered as an unoriginal word order in Arabic. An argument to verify the grammaticality of SVO word order is beyond the scope of the study.

On the other hand, the first argument in focus structures is in the accusative case. Preposed objects are examples of focus structures. Notice the following examples.

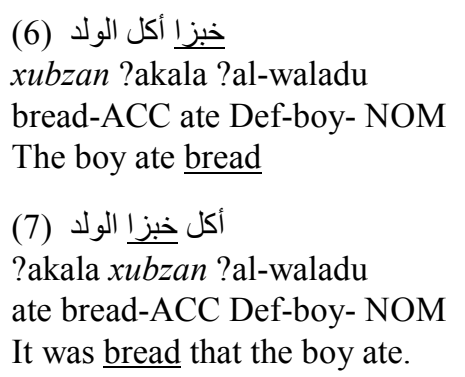

\subsection{Use of Markedness in Literary Texts}

Literary text can simply be described as a piece of writing which requires deviation from norms. Generally speaking, literary language displays a high degree of stylistic dexterity. In literary language, writers use subtle alterations to give vibrancy, depth, and punch. Subtle choices in sentence structure can bring emphasis and convey slightly (or even dramatically) different meanings. Another important issue is old and new information. If one is restarting a point that readers already know, so it shouldn't be emphasized, and it should go either at the beginning or middle of the sentence. New information, new ideas, characters, or places that writers want to emphasize more should go at the end of the sentence. Sentences inevitably follow word order in language. In such a case the sentence is unmarked. If the normal structure is violated for any rhetorical motivation such as emphasis, the sentence becomes marked. Preposing a component in a sentence can be accounted for by the motivation of the writer. Hatim (2004: 230) presents linguistics markedness to be evidence that texts interact with context. Benign deviation from norms seems to be related to text receiver expectations. For example, the sentence "Mad I am not" presupposes the addressee's participation (involvement). Shifts in word order expectancy play a role in the meaning of the text. Nida and others (1983: 36) maintain:

Shifts involve an increase in markedness. The tension which is introduced in such shifts between the normal and the non-normal, between the usual and the unusual, between the expected and the unexpected, accounts for the significantly greater impact involved in such shifts.

\subsection{Rendering Markedness in Translation}

There is interrelation between markedness and meaning. In accordance with Baker, a linguistic element is meaningful when it is marked.

Meaning is closely associated with choice, so that the more obligatory an element is, the less marked it will be and the weaker will be its meaning. The fact that adjectives have to be placed in front of nouns in English, for instance, means that their occurrence in this position has little or no significance because it is not the result of choice. On the other hand, putting a time or place adverbial, such as today or on the shelf, say, at the beginning of the clause, carries more meaning because it is the result of choice: there are other positions in which it can occur. This is one aspect of the relationship between meaning, markedness, and choice. A second aspect has to do with the degree of expectedness or unexpectedness of a choice. The less expected a choice, the more marked it is and the more meaning it carries; the more expected, the less marked it is and the less significant it will have. For example, it is possible but uncommon to place a complement in initial position in English clause (as in Beautiful were her eyes, rather than Her eyes were beautiful). (1992: 129-130)

Hatim (2004) relates linguistic markedness with textual variables such as 'evaluativeness'; the comparison or assessment of concepts, belief systems, etc. Evaluativeness means that linguistic markedness could be 'contextually motivated and functional' or 'merely a systemic matter opted for almost by default' (2004: 231). The translator should figure out the rhetorical motivation behind the choice of linguistic markedness. According to Hatim (2004: 235) the translator's homework is to decipher intentions and motivations behind the use of linguistic markedness.

The reader must first appreciate this deviation for what it is and ascertain that it is contextually motivated. Deviations can be mere aberrations due to linguistic incompetence or inattentiveness, in which case the deviation becomes gratuitous and should therefore be ignored. On the other hand, deviations may be meaningful and must therefore be recognized and heeded as such. (Hatim 2004: 241)

Therefore, linguistic markedness is bound up with discursive (relevant cultural code), textual (here evaluativeness), and genre-related variables (2004: 235).

Texts do not occur in a contextual vacuum. At one level, they tend to exhibit specific discursive affiliations, which make them part of wider belief and value systems, explicit and implicit ideologies, and a diverse range of sociocultural perspectives on such areas of sociocultural life ... At a different level, texts tend to function within well-defined genres that ground the interaction in conventionally recognized 'communicative events"'. (Hatim 2004: 241)

In fact, Hatim draws heavily on contrastive linguistics, 
critical discourse analysis and stylistics to explain linguistic markedness. Hatim argues that most source language nonordinariness constructions are rendered by target language non-ordinary usage. However, he maintains the importance of the dynamic equivalence; markedness should be rendered dynamically, not formally (2004: 236). He gives the example of the highly marked use of Nominal arrangement in Arabic. If it is formally rendered into English, it "would be perceived as unmarked in English and the rhetorical point could thus be lost on an English-speaking reader. There must be some sort of adjustment or modification; for example, "recasting the ST Nominal structure ... into a cleft construction in English: It was X which...." (2004: 237).

"Through dynamic equivalence (Nida 1969; 1964), we can thus cater for a rich variety of contextual values and effects which utterances carry within texts and which formal equivalence and literal translation, each in its own specific way, would simply fail to convey". (Hatim 2004: 237)

Hatim advocates the use of more drastic forms in the restructuring stage to avoid meaningless literalism. He also stresses the fact that perception of markedness is universal. Thus, any degree of non-ordinariness can be rendered on condition that the translator preserves the equivalent effect of that non-ordinary instance of language use. He opens up to the pragmatic equivalence which includes the interventions of the language user and the purpose of the utterance.

Dickens and others (2002) argue that in translating from Arabic to English, "if the word order of the original Arabic can be roughly maintained in the English, this will often reproduce the original theme-rheme structure, because English and Arabic both have a tendency to start with the most thematic element and end with the most rhematic element (2002: 119). In general, the translator is required to preserve the thematic structure of the original text without distorting the target text. Baker (1992) stresses that if there is no link between the themes of the above clause or between a rheme and a following theme, the text will be "disjoined and lacks orientation" (1992: 125).

The selection of an individual theme of a given clause in a given text is not in itself particularly significant. But the overall choice and the ordering of themes plays an important part in organizing a text and providing a point of orientation for a given stretch of language. (1992: 126)

The aim of choosing a particular theme is to "foreground a particular element as the topic of the clause or its point of departure" (1992: 131).

\section{Analysis}

Let us now start analysis of data to recognize what options a translator has for handling potentially linguistic makedness in the Arabic translated texts of Poe's The Black Cat, The Tell-Tale Heart and Woolf's A Haunted House. In this part of the article, we are analyzing some extracts with the aim of finding how translators dealt with potentially marked items in such texts. First, we will examine argument fronting such as objects and complements fronting, then we will consider adjuncts fronting.

Argument fronting is more salient than adjunct fronting. Markedness is highly achieved via the fronting of objects and complements which is much more marked than the fronting of adjuncts in English because objects and complements are fairly restricted in position (Baker 1992:133). In the following examples the reported speech clause functions as an object. Now consider the mistranslation of reported speech which is not marked in English. The literal translation results in false markedness and distortion in the translation of Virginia Woolf's A Haunted House:

(8) "Safe, safe, safe," the heart of the house beats proudly.

$$
\text { "آمن ، آمن ، آمن" يخفق قلب البيت بز هو (البيت المسكون ، ص 11) }
$$

The structure is literally transferred from the source text (ST) to the target text (TT) without taking into account the Arabic word order. There is a shift in the translation because it shows focus structure by fronting the object. It should be translated as

$$
\text { يخفق قلب البيت بزهو "آمن ، آمن ، آمن" }
$$

Yet, the translation of the following sentence follows the Arabic word order.

(9) "Here we left it", she said.

$$
\text { (البيت المسكون، ص 9 ) قالت "هنا تركناها"، }
$$

The noun clause "Here we left" functions as an object. In English it is unmarked that reported speech clause comes before or after the subject and the verb. But in Arabic the verb and the subject come first before the reported speech. Here are two other examples from Virginia Woolf's $A$ Haunted House:

(10) "Here we slept", she says.

$$
\text { تقول "هنا نمنا" (البيت المسكون ، ص 10) }
$$

(11) "Safe, safe, safe", the heart of the house beats proudly.

$$
\text { ردد نبض البيث بنعومة: "آمن ، آمن ، آمن" (البيث المسكون ، ص 9) }
$$

Consider the use of 'alienating' effect; the use of "an inanimate object" [which is 'house'] as "the subject of an action predicate" (Hatim 2004: 232). This example is figurative reported speech; the heart of the house seems to beat saying "safe, safe, safe".

Let us examine the following example of complement fronting from Virginia Woolf's A Haunted House:

(12) So fine, so rare, coolly sunk beneath the surface the beam I sought always burned behind the glass. 


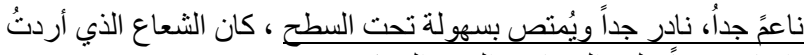

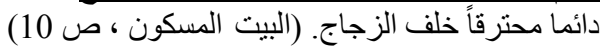

The fronting of complements in Arabic is not textually adequate. It can be compensated in Arabic by using emphatic devices such as 'نإ'. It can be better translated as:

$$
\text { خلف الزعاع الناعم النادر الباهت تحت السطح الذى دائما ما أردت أن يحترق }
$$

Lost markedness is a possible problem in literary translated works. The original text is loaded with marked items. An example of lost markedness can be seen in the following:

(13) Mad indeed would I be to expect it, .... (The Black Cat)

$$
\text { سوف أكون مجنونا لو توقعت أن تصدقو ا ذلك (القط الأسود ، ص 11) }
$$

In this extract, the translator also ignores markedness. Here is another example of complement fronting.

(14) Yet, mad I am not. (The Black Cat)

$$
\text { غير أننى لست مجنونا (القط الأسود ، ص 11) }
$$

An example of a good translation of complement fronting can be seen in the translation of The Tell-Tale Heart.

(15) TRUE! Nervous, very, very dreadfully nervous I had been and am

$$
\text { مجنون .. مجنون ، هذا هو ما ينادوننى به. إننى حقا عصبى... (القلب الو اشى }
$$

The complement is fronted and focused in the translation. It preserves markedness which is a textual feature of the Gothic genre. Therefore, any failure in observing markedness in the Gothic genre would result in loss of meaning and consequently loss of effect on the target reader.

Thematic choice is important in literary texts because it indicates the writer's point of departure. Thematic choice means selecting a clause element as a theme. According to Baker (1992: 129), "some choices are meaningful than others, because they are more marked than others". Thematizing place and temporal adjuncts is very common in descriptive and narrative texts. Baker argues that conjunctions and disjuncts usually come at the beginning of English clauses because they are not part of the basic thematic structure (1992: 123). In the Hallidayan model the adjunct theme is partially marked because adjuncts are allowed to occur in the beginning of the English sentence. Consider the following example from the translation of Woolf's A Haunted House that shows how an original text can be contextually motivated in respect of linguistic markedness.

(16) From room to room they went, hand in hand, lifting here, opening their, making sure

$$
\begin{aligned}
& \text { من غرفة لأخرى كانا ينتقلان يدا بيد يرفعان شيئا ويفتحان هناك ، يتأكدان }
\end{aligned}
$$

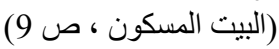

The underlined adjunct in the source text is partially marked. However, the underlined adjunct in the translation seems to be topicalized because, according to language conventions in Arabic, the adjunct is part of the predicate. The fronting of the adverbial phrase in the English sentence is partially marked because the text here is descriptive; it is common to begin with adverbs of place in descriptive literary texts. Therefore, the translation looks natural. It preserves the thematic patterning of the original without distorting the target text.

The underlined fronting of adjuncts can be noticed in the translation of Poe's The Tell-Tale Heart.

(17) Hearken! And observe how healthily, and how calmly, I can tell you the whole story.

$$
\begin{aligned}
& \text { اسمع وسوف ترى بنفسك كيف أبدو هادئا وأنا أقص عليك القصة بأكملها }
\end{aligned}
$$

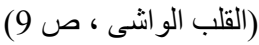

The imperative "Hearken" and the fronting of the adjunct "how healthily and how calmly" are used to motivate the addressee's involvement. The translation preserves the markedness of the original by translating the adjunct as a complete sentence.

Subordination is another aspect of the relationship between meaning and markedness and choice. In English it is unmarked to place the adverbial clause before the main clause in narrative texts. Notice the underlined subordinate clause in the following sentence from Virginia Woolf's $A$ Haunted House:

(18) Wandering through the house, opening the windows, whispering not to wake us, the ghostly couple seek their joy.

$$
\begin{aligned}
& \text { متجولين عبر المنزل ، فاتحين النوافذ ، هامسين خشية إيقاظنا ، يبحث }
\end{aligned}
$$

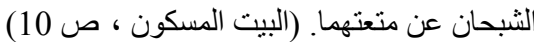

The translation overloads the meaning. It is better to place the adverbial clause after the main clause in Arabic. To place the adverbial clause before the main clause is against the Arabic norms. Consider an example of using the adverbial clause in Arabic:

$$
\begin{aligned}
& \text { و لا تحسبن الذين قتلو ا فى سبيل الله أمو اتا بل أحياء عند ربهم يرزقون } \\
& \text { فرحين بما آتاهم الله من فضله (170-169 آل عمران) }
\end{aligned}
$$

If we examine the relation between the two clauses and conceive it as clausal relationship; the second clause represents the reason for the first clause, we must reverse subordination structure in the Arabic translation:

$$
\text { يتجول الثبحان عبر المنزل ويفتحا النوافذ ويهمسا كيلا يوقظانا ليبحثا عن }
$$$$
\text { متعتهم }
$$

In fact, reversing subordination is considered a kind of idiomatic translation. Dickens (2009) explains that "Arabic more readily allows both adjuncts and disjuncts in final 
(rhematic) position to convey foreground information (2009: 1102). However, the translator could have avoided reversing subordination by using circumstantial clause in Arabic which can be equal to temporal clause in English. Therefore, if we consider the subordinate clauses as cum circumstantial, meaning "while they are wandering through the house, opening the windows, whispering not to wake us", then we put it in final position in Arabic. In Arabic there are 3 ways of constructing circumstantial clauses. Clauses of circumstances are usually introduced by the conjunction " or zero conjunction or by using a non-finite form of the verb:

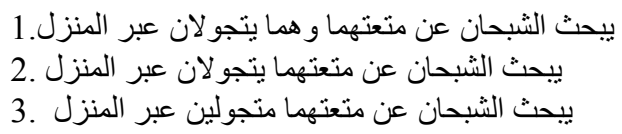

In the above example, a potential translator has to make a decision regarding how a subordinate clause is translated. In translating from English, very close attention should be paid to how specific the action in the subordinate clause is; if it is very specific, we treat the clause as temporal; if vague or general, we treat the clause as circumstantial. Once the translator reaches a reasoned decision, he/she should make the target text free from such false markedness. The same problem can be seen in the translation of the underlined subordinate clause.

(19) Stooping, holding their silver lamp above us, long they look and deeply.

منحنيين وحاملين مصباحهما فوقنا ، يتأملان بعمق و أناة يجمدان لمدة طويلة

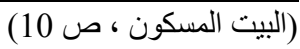

The next example is taken from the translation of Poe's the Black Cat:

(20) For the most wild, yet most homely narrative which I am to pen, I neither expect nor solicit belief.

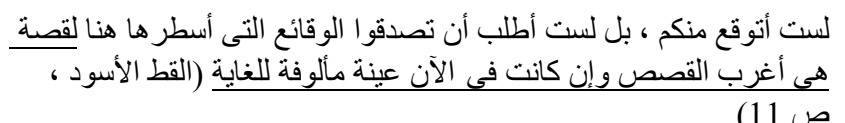

The underlined structure in the translation is not topicalized because it began with the main clause. Markedness is lost in the translation.

\section{Conclusion}

Markedness is used in Edgar Allan Poe's The Black Cat, The Tell-Tale Heart and Virginia Woolf's A Haunted House as a literary device. English literary texts and their Arabic translations differ in their manipulation of linguistically marked, topicalized and focus items. Dickens and others (2002) state that Arabic and English present information sententially in the same order, which is theme-rheme order. However, in the process of translation it is not always possible to maintain the same word order to keep the same theme-rheme structure (Dickens et al. 2002: 119). One of the findings of the study is that Arabic has greater syntactic flexibility than English: while English uses word order to determine the function of each word in a sentence, Arabic uses case markings and agreement to identify the grammatical functions of words and to distinguish topiccomment structures and focus structures. Thus in Arabic it is relatively easy to emphasize a certain part of the sentence via manipulating the word order of a sentence or via emphatic devices such as 'إن'. In English one can create such emphasis only through restructuring the sentence. Second, Arabic and English use coordination and subordination in different ways. These differences in Arabic and English texture cause difficulty in translating Gothic short stories. Another finding of the study is that in translating Gothic genre the denotative meaning of the source text could be maintained even under the specific constraint of theme-rheme equivalence; however, the thematic structure of the text were almost inevitably altered. The study concludes that thematic structure is an important aspect of the translation of Edgar Allan Poe's The Black Cat, The Tell-Tale Heart and Virginia Woolf's A Haunted House.

\section{Abbreviations}

ACC: accusative

Def: definite

NOM: nominative

MSA: Modern Standard Arabic

\section{Appendix: Transcription Conventions}

In transcribing the examples, the study uses the following symbols:

\section{Consonants}

\begin{tabular}{|c|c|}
\hline Arabic & symbol \\
\hline ب & /b/ voiced bilabial stop \\
\hline$ت$ & $/ \mathrm{t} /$ voiceless dental stop \\
\hline$\dot{H}$ & $/ \theta /$ voiceless interdental fricative \\
\hline ج & $/ \mathrm{j} /$ voiced alveo-palatal affricate \\
\hline$\tau$ & /H/ voiceless pharyngeal fricative \\
\hline$\dot{\tau}$ & /X/ voiceless uvular fricative \\
\hline د & /d/ voiced dental stop \\
\hline ذ & $/ ð /$ voiced interdental fricative \\
\hline J & $/ \mathrm{r} /$ alveolar trill \\
\hline j & /z/ voiced dento-alveolar fricative \\
\hline س & /s/ voiceless dento-alveolar fricative \\
\hline ش & $/ \check{\mathbf{s}} /$ voiceless alveo-palatal fricative \\
\hline ص & /S/ voiceless dento-alveolar emphatic fricative \\
\hline 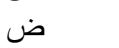 & /D/ voiced dento-alveolar emphatic stop \\
\hline b & /T/ voiceless dento-alveolar emphatic stop \\
\hline ظ & /Z/ voiced dental emphatic fricative \\
\hline$\varepsilon$ & $/ ؟ /$ voiced pharyngeal fricative \\
\hline$\dot{\varepsilon}$ & /G/ voiced uvular fricative \\
\hline ف & /f/ voiceless labio-dental fricative \\
\hline ق & /q/ voiceless uvular stop \\
\hline
\end{tabular}


5] $\quad / \mathrm{k} /$ voiceless velar stop

ل / / / / voiced alveolar lateral

? $\quad / \mathrm{m} /$ voiced bilabial nasal

ن $\quad / \mathrm{n} /$ voiced alveolar nasal

- $\quad / \mathrm{h} /$ voiceless glottal fricative

- $\quad / ? /$ voiced glottal stop

و / / / voiced bilabial approximant

$\checkmark \quad$ /y/ voiced palatal approximant

\section{Vowels:}

/i/ high front. /i:/ its long counterpart /u/ high back /u:/ its long counterpart /a/ low central /a:/ its long counterpart

\section{References}

[1] Baker, Mona. 1992. In Other Words: A Course Book On Translation. London, New York: Routledge.

[2] Bakir, Murtadha. 1979. Aspects of Clause Structure in Arabic: A study in word Order Variation in Literary Arabic. Indiana University linguistics Club, Bloomington, Indiana. Chomsky, N.1986.Barriers. MIT Press, Cambridge Mass.

[3] Berry, Margaret. 1995. 'Thematic options and success in writing'. In Ghadessy, M., (ed.), Thematic Development in English Texts, London: Pinter (pp. 55-84).

[4] Bloor, Thomas and Bloor, Meriel. 1995. The Functional Analysis of English: A Hallidayan Approach. London: Edward Arnold.

[5] Dickens, James, Hervey, Sandor and Higgins, Ian. (2002) Thinking Arabic translation, a course in translation method: Arabic to English. New York: Routledge.

[6] Dickens, James (2009) "Junction in English and Arabic: Syntactic, discoursal and denotative features" in Journal of Pragmatics Vol. 42, pg. 1076-1136

[7] Ford, David. 2009. "The Influence of Word Order on Modern Standard Arabic Information Structure", GIALens (Special Electronic Publication of the Graduate Institute of Applied Linguistics), Vol. 3, No 2(April 2009). Available on line: http:/www.gial.edu/documents/gialens/vol3-2/ford-infostructure-and-word-order-msa.pdf

[8] Fowler, Roger. 1986. Linguistic Criticism. Oxford: Oxford University Press.
[9] Halliday, Michael. 1985. An Introduction to Functional Grammar. London: Arnold.

[10] Halliday, Michael. 1994. An Introduction to Functional Grammar (Second Edition). London: Arnold.

[11] Hatim, Basil. 2004. "The translation of style: linguistic markedness and textual evaluativeness". Journal of Applied Linguistics. Vol 1.3 2004:229-246

[12] Hogle, Jerrold. 2002. 'Introduction'. In Hogle, J.E (Ed.). The Cambridge Companion to Gothic Fiction. Cambridge: Cambridge UP.

[13] Kirkwood, Henry. 1979. "Some Systemic means of Functional Sentence Perspective in English and German". In D. Nehls (ed.) Studies in Contrastive Linguistics and Error Analysis. Heidelberg. Groos.

[14] Jones, Stephanie. 2010. "Exploring Gothic Fiction: A CorpusBased Analysis". Thesis, The University of Edinburgh. Available on line: http://www.era.lib.ed.ac.uk/handle/1842/5351

[15] McEvoy, Emma. 2007. "Gothic and the Romantics". In Spooner, C. and E. McEvoy (Eds.). 2007. The Routledge Companion to Gothic. London and New York: Routledge.

[16] Menacre, Mohamed. "Translating Arabic into English: Basic considerations in word order" Meta: journal des traducteurs / Meta: Translators' Journal, vol. 40 no. 4, 1995, pg. 606-613.

[17] Nida, E. A. , Louw J. P. , Snyman, A. H., and Cronje , J. W. 1983. Style and Discourse: With special reference to the text of the Greek New Testament, by Eugene Nida and others (Bible Society of South Africa)

[18] Sedgwick, Eve. 1986. The Coherence of Gothic Conventions. New York and London: Methuen.

[19] Primary Sources

[20] Poe, Edgar Allan. 2000. (1843). 'The Tell-Tale Heart'. Trans. By Nadia Farid. In Alghaz. Cairo: General Egyptian Book Organization

[21] Poe, Edgar Allan. 1985. 'The Black Cat'. Trans. By Mohammed Abdel-Samei. Kuwait: Dar Laila and Ma'moun Book

[22] Woolf, Virginia. 2006. A Haunted House. Trans. By Ruqaya Kan'an. Amman: Dar Alshorouq 